\title{
Increased serum phospholipids in epileptic children treated with phenobarbitone
}

\author{
L PAVONE, * G KlOSE, $\dagger$ F MOLliCA,* M LA ROSA,* H GRETEN $\dagger$ \\ From the University Department of Paediatrics, Catania, Italy* and the University Department of Medicine, \\ Hamburg, Germany $\dagger$
}

SUMMARY Plasma lipid concentration and post-heparin lipolytic activity in twenty-two epileptic children treated either with phenobarbitone or sodium valproate were evaluated. An increase of phospholipid was observed in whole blood as well as in the low-density and high-density lipoproteins in patients undergoing phenobarbitone treatment. No change was found in subjects treated with sodium valproate. The enzyme activities were slightly, but not statistically significantly, increased in the two groups compared with the control subjects.

Chronic administration of antiepileptic drugs is often accompanied by untoward side effects including metabolic and endocrine abnormalities. ${ }^{12}$ Moreover some anticonvulsant drugs metabolised by the liver are powerful enzyme-inducing agents, and stimulate the enzymatic activities concerned with steroid hydroxylation, the bilirubin pathway, and lipid synthesis and metabolism. ${ }^{3}$

The purpose of this study was to evaluate plasma lipid concentration in epileptic children treated with two of the most common anticonvulsants: phenobarbitone and sodium valproate. We also measured the post-heparin plasma activity of two enzymes, the lipoprotein-lipase and hepatic triglyceride-lipase, which are directly related to lipid metabolism.

\section{Patients and methods}

Twenty-two children (13 males and nine females) were included in this study. The age range was from 3 to 9 years (mean 7 years). Eighteen patients had grand-mal convulsions, one had petit mal absence, and the remaining three had infantile spasms. Seventeen patients were treated with phenobarbitone $5 \mathrm{mg} / \mathrm{kg} /$ day over a period of 6 months to 8 years (mean 4 years). The serum concentration of this drug varied from 10 to $25 \mu \mathrm{g} / \mathrm{ml}$. Five patients were treated with $20 \mathrm{mg} / \mathrm{kg} /$ day of sodium valproate over a period of 16 months to 3 years (mean 2 years). Blood concentrations of this drug ranged from

Address for reprint requests: Dr L Pavone, Clinica Pediatrica Università, Catania, Viale Doria, Italy.

Received 13 July 1981 and in revised form 14 September 1981 Accepted 26 September 1981
40 to $80 \mu \mathrm{g} / \mathrm{ml}$. Twelve healthy subjects of the same ages and sexes were used as controls. Serum transaminases were within the normal limits in all the patients, and prothrombin activity exceeded $70 \%$.

Blood samples for lipid analysis were taken while the subjects were on ordinary diet in the morning and after fasting for at least 12 hours. Triglycerides and cholesterol were determined in the whole serum on a Technicon Autoanalyzer II as described by Lowry et $a^{4}$ and Bloor. ${ }^{5}$ Triglycerides, cholesterol and phospholipids were also determined by the same methods in the very low, low and high-density lipoprotein fractions separated by sequential ultracentrifugation in a Spinco-L ultracentrifuge. The post-heparin lipolytic activity after intravenous injection of heparin $60 \mathrm{u} / \mathrm{kg}$ body weight was determined by immunochemical methods as described by Greten et al. ${ }^{6}$ The results are expressed as mean $\pm \mathrm{SD}$, the significance of the difference between patients and controls was calculated by Student's $t$ test.

\section{Results}

The table summarises the results:

(a) Subjects treated with phenobarbitone An increase of phospholipids was seen in whole blood as well as in the low-density and high-density lipoprotein fractions, but no significant variations of cholesterol and triglycerides were seen.

(b) Subjects treated with sodium valproate No alteration in any of the parameters studied was seen compared with the control group. Although the post-heparin lipolytic activity was moderately increased in the two groups compared with the controls, the rise was not statistically significant. 
Table Plasma lipid composition and post-heparinic lipolytic activity in epileptic children on phenobarbitone (a) or sodium valproate $(b)$

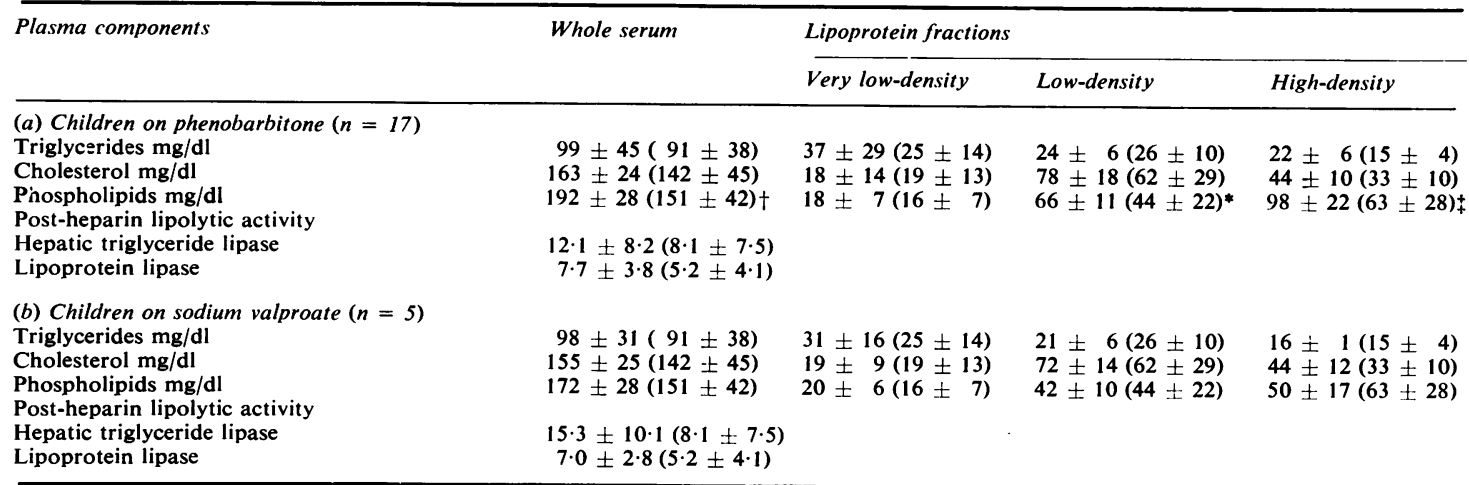

$* \mathrm{p}<0.05 \quad \nmid \mathrm{p}<0.01 \quad \ddagger \mathrm{p}<0.001$.

\section{Discussion}

Both sodium valproate and phenobarbitone are widely used in the treatment of various form of childhood convulsions. Only a few studies on serum lipid composition in patients undergoing antiepileptic treatment have been carried out. Pelkonen et $a l^{7}$ found increased serum cholesterol in 9 out of 11 patients treated with phenytoin $(300-400 \mathrm{mg} /$ day). Blood samples were withdrawn at 3-monthly intervals up to a year after treatment began. The rise in cholesterol was already evident in the first three months (from 6 to $48 \%$ of basal values, mean $19 \%$ ). In sharp contrast with these results, in a much larger series followed over many years, Livingston ${ }^{8}$ did not observe a prevalence of elevated serum cholesterol values in excess of that expected in the general population. Nikkila et al $^{9}$ found increased cholesterol levels in the high-density lipoprotein fraction, but not in the whole serum, in $43 \%$ of 28 adults treated with phenytoin. However a comparison between these data and the results obtained in our study seems inappropriate as our study concerned epileptic children on phenobarbitone and sodium valproate treatment; the earlier studies involved principally adults treated with phenytoin.

We would like to underline the following data obtained from our study: (a) no variation of the lipid pattern was seen in subjects treated with sodium valproate as compared with the controls; (b) on the contrary, we observed a rise of phospholipids in both the whole serum and in the low-density and highdensity lipoprotein fractions in patients undergoing phenobarbitone treatment.

The lipolytic enzymes hepatic triglyceride-lipase and lipoprotein-lipase are supposed to be of hepatic and adipose tissue origin respectively. In our patients no modifications of these enzymes were seen and this indicated that neither phenobarbitone nor sodium valproate interfere with their metabolism. It is not clear how phenobarbitone treatment causes an increase in phospholipids. Since this drug has a stimulating action on numerous microsomal enzymes it is possible that it also increases some enzymatic activities involved in the synthesis of phospholipids.

\section{References}

${ }^{1}$ Reynolds EH. Chronic antiepileptic toxicity: a review' Epilepsia 1975;16:319-52.

${ }^{2}$ Richens A. Drug treatment of epilepsy. London: Kimton, 1976:118-53.

${ }^{3}$ De Wolff FA, Peters ACB, Van Kempen GMJ. Liver enzyme induction in epileptic children treated with phenytoin, or valproate. In: Johannessen JI, Pippenger CE, Schmidt D, Morselli PR, Richens A, Meinardi H, eds. Antiepileptic therapy: Advances in drug monitoring. New York: Raven Press, 1980:19-25.

${ }^{4}$ Lowry OH, Roberts NR, Leiner KY. The quantitative histochemistry of brain. J Biol Chem 1954;207:1-5.

${ }^{5}$ Bloor WR. The oxidative determination of phospholipid in blood and tissue. J Biol Chem 1929;82:273-6.

${ }^{6}$ Greten H, De Grella R, Klose G, Rascker W, De Gennes JL, Gjonne E. Measurement of two plasma triglyceride lipases by an immunochemical method: studies in patients with hypertriglyceridemia. $J$ Lip Res 1976;17:203-10.

${ }^{7}$ Pelkonen R, Fogelholm R, Nikkila EA. Increase in serum cholesterol during phenytoin treatment. $\mathrm{Br} \mathrm{Med}$ $J$ 1975;4:85.

${ }^{8}$ Livingston S. Phenytoin and serum cholesterol. Br Med $J 1976 ; 1: 586$.

${ }^{9}$ Nikkila EA, Kaste M, Ehnholm C, Viikari J. Elevation of high density lipoprotein in epileptic patients treated with phenytoin. Acta Med Scand 1978;204:517-20. 